広域避難場所における防火性からみた緑の評価のための

リモートセンシング調査

\title{
RESEARCH FOR EVALUATION OF VEGETATION ON FIRE PREVENTION IN SAFETY EVACUATION AREA USING REMOTE SENSING
}

鍵 屋 浩司*，尾島 俊 雄**

Koji KAGIYA and Toshio OJIMA

In this study we evaluated the quality of vegetation for fire prevention for the safety evacuation area in Tokyo ward area using satellite remote sensing.

We analyzed multi-temporal data of Landsat TM to get the distribution data of deciduous vegetation. The safety evacuation areas are classified by their effective area and composition of land cover into eight types to consider measures for more preventive of fire spreading.

As solution, we showed necessity to put evergreen broad leafed trees on the fringe of the safety evacuation area.

\section{keywards: remote sensing, Landsat, mult-temporal data, fire prevention, species of trees, safety evacuation area \\ リモートセンシンダ、ランドサット、マルチテンポラルデータ、防火、樹種、広域避蜼場所}

1. はじめに

\section{1-1 火災と緑}

市街地火災、特に地震火災におうる緑の延焼防止効果や、輻射

熱遮䉼効果は、関東大震災や阪神・淡路大震災等て報告されてきた。

田中 (1923) ${ }^{1}$ は関東大震災後の旧東京市内 26 力所 $\sigma$ 公園・神社 仏閣・私邸等それぞれの面積・樹木本数・樹木分布などと被害状況 との関係につい、、森林・樹木の防火効果の観点力ら考察している。

阪神・淡路大震災では、系谷・北澤 $(1995)^{2)}$ が震災時 $の$ 公園緑地 の利用状况や地震火災の焼け止まりの調査をしている。特に緑によ る焼け止まりに関する調査では、造園学会の報告(1995) 3゙が詳しい。 地震火災以外の大規模火災としては、新潟大火(1955) ${ }^{0}$ の報告や、 酒田大火(1976) の) 報告でも緑の延焼方止効果が指摘されている。

こうした過去の事例が示卞ように、緑の防火性を活用した都市 防災対策は有効であるといえる。

\section{1-2 広域避難場所}

災害対策基本法（昭和 36 年法律第 223 号）の規定に基づく地域 防災計画の避保㑣点として、自治体によりその名称は異なるが、広 域避難場所もしくは避難場所が指定されている。

東京都の場合、都市におう地震火災が拡大し、生命に危険が
及ぶような事態こおけける安全な避難場所として、区部を対象に現在

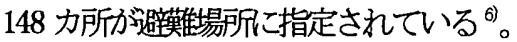

この避難場所の指定にあたっては、周辺の市街地大火による輻 射熱力ら安全な有効面積を理論式より算定 ${ }^{\text {米 }}$ 所を避難場所の候補としている。

ここで各避難場所面積に対する有效面積の割合と、避難語十画人 ロ 1 人あたり有効面積との関係を図 $1^{7)}$ に示す。

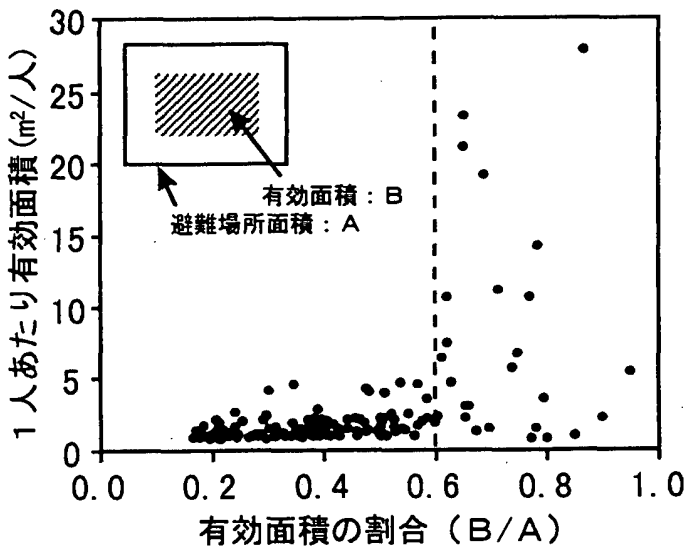

図 1 一人当たり有効面積と有効面積の割合との関係
* 早稲田大学理工学総合研究センター 助手・工修

** 早稲田大学理工学部建築学科 教授. 工博
Research Assoc., Advanced Research Institute for Science and Engineering, Waseda University, M. Eng.

Prof., Dept. of Architecture, School of Science and Engineering, Waseda University, Dr. Eng. 
これによると、有効面積の割合が $60 \%$ 以下となるような規模の 小さな避傼場所では、人あたり有効面積が極めて低、のが実情で ある。このことは、避難場所周縁部の防火対策を積極的に進める必 要性を示している。

現在、地震火災からの安全確呆には、輻射熱から安全な面積の 確呆や周辺部に耐火建造物を配置することに重点が置力れている。 しかし、これらの避蜼場所が平常時には公共性の高い用途に供され、 また都市環境緩和や景観の観点も考慮すると、防火性の高い緑を配 置するほうがより効果的である。

\section{1-3 都市防災対策におけるリモートセンシングの位置づけと 研究目的}

都市スクールのようなマクロな計測を行う際には、その計測対 象をあらかじめ空間軸に沿って整理しておく必要がある。表 1 は、 Space Modular Coordination Chart ${ }^{8}$ に基づき、空間軸により各種 防災施設を整理したもの 9 である。

ここで、 S モデルは地上計測（グランドトウルース）によって、 H(1)モデルは航空機Ｈ(2)からは人工衛星をプラットフォームとす るリモートセンシングによる計測が可能である。本研究で対象とす る避難場所は、表 1 の H(2)〜H(3)モデルに対応しており、環境場 は 10km から 100km、画素は 10〜100 mのスケールに相当する。

\section{表 1 各種防災施設の位置つけ}

\begin{tabular}{|c|c|c|c|c|}
\hline Model & $S$ & $H(1)$ & $\mathrm{H}(2)$ & $H(3)$ \\
\hline FIELD $(\mathrm{m})$ & $10^{2}$ & $10^{3}$ & $10^{4}$ & $10^{5}$ \\
\hline $\operatorname{MESH}(m)$ & 1 & $10^{1}$ & $10^{2}$ & $10^{3}$ \\
\hline $\operatorname{PIXEL}(\mathrm{m})$ & 0.1 & 1 & $10^{\prime}$ & $10^{2}$ \\
\hline 避難系施設 & \begin{tabular}{|l} 
公開突地 \\
突
\end{tabular} & $\begin{array}{l}\text { 一䢘笨合場所 } \\
\text { 囉所 }\end{array}$ & 広域避辨場所 & 厷域防災拠点 \\
\hline $\begin{array}{l}\text { 延焼遮断。 } \\
\text { 火災防御系 } \\
\text { 施設 }\end{array}$ & $\begin{array}{l}\text { 延燒防止線 } \\
\text { 耐火建物 } \\
\text { 消防水利 }\end{array}$ & 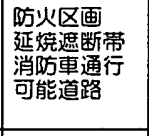 & $\begin{array}{l}\text { 市街地内空地 } \\
\text { 緑地保全地区 } \\
\text { 生釐緑地 }\end{array}$ & $\begin{array}{l}\text { 邚外空地 } \\
\text { 市街化調整 } \\
\text { 区域 } \\
\text { 近视緑地保全 } \\
\text { 地域 }\end{array}$ \\
\hline 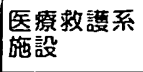 & 救婹所 & 救援所 & 敖急病院 & 㫟点病院 \\
\hline 瀚送系施設 & & 配給拠点 & \begin{tabular}{|l|} 
配給势点 \\
㑿樌所
\end{tabular} & 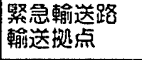 \\
\hline \begin{tabular}{|l} 
情報広報系 \\
施設
\end{tabular} & 個人 & $\begin{array}{l}\text { 町村 } \\
\text { 地区防災基地 }\end{array}$ & $\begin{array}{l}\text { 市区 } \\
\text { 地域防災基地 } \\
\text { 城報無線 }\end{array}$ & 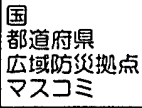 \\
\hline
\end{tabular}

一方、防火性からみた広域辟勒場所における緑の実態調査は、従 来は実地調查による植生の目視判別に依存していた。従って、都市 全域における調査を行う場合、多大の時間と労力が必要となるため 広域避蜼場所すべてについて調査した事例はない。

加えて、広域避難場所における有効面積拡大を目標とした緑化 基淮は現在のところ見られない。都市緑化推進のためには、防災面 からも緑の機能を考慮した事前竐平価手法および基淮が有効である。

以上より本研究は、緑の防火性の観点加東京都区部の広域辟 難場所の緑化言十画のための基礎調查として、広域を効率的に調查す る手段である地球観泪衛星によるリモートセンシングを用い その 応用可能性について検討する。さらにその結果をふまえ、広域避難 場所一の緑の防火性を考慮した緑化手法を提案寸る。

\section{2. 防火性からみ十緑}

\section{2-1 緑の防火性二開する従来研究}

緑の防火性とは緑の輻射熱遮断効果および、枝葉の非着炎性に よる延焼方止効果の反映した性質をいう。

この $2 つ の$ 効果に関する従来研究として、井上・中元(1951) は植物の発焔までの平均時間の測定や、不発售性の現象の発生率の 算出およひ葉の厚さと含水率との関係を考察した。村(1948) は、ガス炉と電気炉を用いて、葉の厚さと脱水時間との関係队着焔 性について実験した。柎・加藤(1948) ${ }^{12}$ は、樹木の防火性につい て樹葉の含水量から実験を行った。

都市防災計画に関車した研究として岩河(1984) (13) は樹木の遮蔽 効果について野外実験を行い、都市における樹木の防火機能につい て研究した。高橋・福嶋(1980) ${ }^{10}$ は、広域辟難場所㧍引る植生の防 火機能について、既往文献等により植物の防火性を種ごとに整理し、 植物の防火性を大・中・小・色険の 4 類型に分類した。また福嶋・ 門屋(1990) ${ }^{\text {פ }}$ は都市公園の防火機能に関して、樹木の構成と配置の 研究を行っている。

\section{2-2 防火性による緑の分類}

緑の防火機能に関する以上の知見を整理すると、概る次に示す ような緑力゙防火性力滈いといえる ${ }^{10}$ 。

1) 樹木である

2）葉は広葉て密生している

3）葉の含水量が多く葉が厚い

4) 常緑である

5）葉の樹脂分が少ない

すなわち、1) 火災面加放射状に直進する輻射熱に対して、樹木 は障害物として輻射熱を遮蔽する。また熱気流の動きを妨げるため 火炎が流れるのを防ぎ、飛来する火の粉を阻止する。

2) 1)における遮蔽効果は、樹冠の空隙が少ない ほど䳸熱や防風の 効果が大きくなる。

3) 水分が多いと比熱が大きいため、葉か熱せられたとき、葉温が 上昇しにくい。また葉が厚いと水分がなくなるまでの時間が長くか かるため、葉に引火する時間が延びる。

4) 火災恃冬季に多く発生することから、落葉樹よりも常緑樹 方が有効である。

5)葉に樹脂分のある樹木 例えばマツ・スギなどは一旦引火する と勢いよく燃える。さらに針葉樹㵩力細く、枯れ葉力残存して延 焼性が大きい。

以上をふまえて防火性から緑を分類した（表2）。すなわち、最 も防火性に優九るのが常緑広葉樹であり、次に落葉広葉樹、針葉樹、 そして常緑草と夏緑性の草は防火性が低い。

表2 防火性からみた緑の分類

\begin{tabular}{|l|c|c|c|}
\hline \multirow{2}{*}{ 緑の種類 } & \multicolumn{2}{|c|}{ 葉の有無 } & \multirow{2}{*}{ 防火 } \\
\cline { 2 - 3 } & 夏季 & 冬季 & \\
\hline 常緑広葉樹 & $\bigcirc$ & $\bigcirc$ & 最適 \\
\hline 落葉広葉樹 & $\bigcirc$ & $\times$ & \multirow{2}{*}{ 適 } \\
\hline 針葉樹 & $\bigcirc$ & $\bigcirc$ & \\
\hline 常緑草 & $\bigcirc$ & $\bigcirc$ & 不適 \\
\hline 夏緑性の草 & $\bigcirc$ & $\times$ & \\
\hline
\end{tabular}




\section{3. リモートセンシングによる土地被覆の把握 3-1 解析の概要}

解析に使用したデー夕は、 Landsat TM の東京周辺のデー夕 (D107-035)である。そして落葉性の植生の分布を把握寸るために、 夏季・冬季のマルチテンポラルデータの解析を行った。

夏季・冬季のデータとして、1987 年 7 月 24 日と 1991 年 1 月 8日のデータを用いた。解析対象範用は東京都区部を含む東西約 $40 \mathrm{~km}$ ・南北約 $30 \mathrm{~km}$ である。

落葉性の植生の把握については、夏季・冬季の土地被覆分類結 果を重悋合灺、夏季湗木や草地と分類され、冬季にそれ以外に 分類されたものを、それぞれ落葉樹および夏緑性の草とした。

\section{3-2 マルチテンポラルデータの解析}

落葉性の植生の把握において、夏季・冬季のデータを画素単位 で重悋合わせるため、夏季のデー夕を基淮にして冬季のデー夕に対 して幾何補正を行った。ここではGCP (地上基準点)を 12 力所設 定して幾何補正したところ、補正誤差は各基淮点ともに 1 ピクセル 末満であった。

緑の種類の把握は、教師付最尤法による土地被覆分類によった。 分類項目は夏季・冬季それぞれについて、広葉樹・針葉樹・草地・ 裸地・水域・建造物の6つのクラスとした。

トレーニングエリアは、現存植生図 171819おおさ航空写真により、 対応寸る画素がピュアピクセルとなるように選定した。以下に各ク ラスのトレニングエリアを示す。

- 広葉樹 : 明治神宮・自然教育園

(樹種 : スダジイ・コナラ・シラカシ)

- 針葉樹 : 狭山湖付近の山林・生田付近の山林

(樹種 :アカマツ・スギ・ヒノキ)

・草地 : 多摩川河川㩤・荒川河川旉

・水域 : 東京湾・多摩川・隅田川・荒川・多摩川㜔艇場

- 建造物 : 銀座・秋葉原・京島・池袋・大井町の建造物

植生分布の把据にあたっては、夏季・冬季の土地被覆分類結果を 重效合わせ、夏季に広葉樹や草地と分類され、冬季にそれ以外のク ラスに分類された画素をそれぞれ落葉広葉樹・夏緑性の草とした。 一方、夏季と同じクラスに分類された画素については、常緑広葉 樹・常緑性の草とした。な捦擛樹は、夏季に針葉樹と分類された 画素は冬季も針葉樹とした。

以上から、表 2 の防火性から見た緑の分類こ基づき、常緑広葉 樹·落葉広葉樹・針葉樹·常緑草・夏緑性の草・裸地・水域・建造 物の8項目の土地被覆分布データを作成した。

\section{3-3 土地被覆分類の精度の評価}

夏季・冬季のデー夕の土地被覆分類における分類精度の評価は、 土地被覆分類で用いたトレーニングエリアとは别に、分類精度評価 用に、事前に各クラスごとにサンプルエリアを抽出した。そして、 土地被覆分類後に各サンプルエリアにおいて当該クラスに分類さ れた割合て評価した。

なお、精度評価に用いたサンプルエリアは、トレーニングェリ アと同様に現存植生図およひ航空写真を用いエエリア内の土地被覆 が均質になるような場所を選んだ。

これは、分類精度評価として最もよく用いられるものである ${ }^{20}$
表 $3 \cdot 4$ に 夏季・冬季それぞれのサンプルエリアの分類精度を示 す。これによると、夏季デー夕における平均精度は $80.4 \%$ 、冬季 データについては $80.2 \%$ あった。

表 3 各クラスの分類精度 (夏季)

\begin{tabular}{|c|c|c|c|c|c|c|c|c|}
\hline & 広葉樹 & 針葉樹 & 草地 & 裸地 & 建造物 & 水域 & 未分類 & 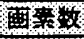 \\
\hline 広葉澍 & 73.5 & 16.0 & 0.9 & 0.0 & 0.6 & 0.0 & 8.9 & 325 \\
\hline 針葉樹 & 21.4 & 66.7 & 0.9 & 0.0 & 0.0 & 0.0 & 11.1 & $1 / 2$ \\
\hline 草地 & 0.0 & 0.2 & 84.7 & 0.0 & 0.0 & 0.0 & 15.1 & 483 \\
\hline 裸地 & 0 & 0 & 0.0 & 83.0 & 0.0 & 3.0 & 14.1 & 135 \\
\hline 建造物 & 0.0 & 0.0 & 0.0 & 1.1 & 90.3 & 0.0 & 8.6 & 1311 \\
\hline 水域 & 0.0 & 0.0 & 0.0 & 0.0 & 1.6 & 83.9 & 14.5 & 573 \\
\hline
\end{tabular}

表4 各クラスの分類精度 (冬季)

\begin{tabular}{|c|c|c|c|c|c|c|c|c|}
\hline & 広菜徍 & 針案徼 & 草地 & 裸地 & 建造物 & 水域 & 末分類 & 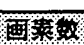 \\
\hline 広葉澍 & 74.3 & 9.1 & 0.0 & 0.0 & 0.0 & 0.0 & 16.6 & 175 \\
\hline 針葉樹 & 17.2 & 72.0 & 0.0 & 0.0 & 2.2 & 0.0 & 8.6 & 93 \\
\hline 草地 & 0.0 & 0.0 & 83.9 & 0.0 & 0.0 & 0.0 & 16.1 & 93 \\
\hline 裸地 & 0.0 & $\overline{0.0}$ & 0.4 & 83.9 & 0.8 & 0.0 & 14.9 & 248 \\
\hline 建造物 & 0.0 & 0.4 & 0.0 & 1.4 & 82.8 & 0.7 & 14.7 & 941 \\
\hline 水域 & 0.0 & 0.1 & 0.0 & 0.0 & 1.6 & 84.4 & 13.9 & 1856 \\
\hline
\end{tabular}

\section{4. 広域避保場所における緑の評価 \\ 4-1 概要}

広域避蜼場所は、地震火災時の安全な避難の場であるとともに、 平常時は公共性の高い用途に供されていることを考えると、良好な 都市環競形成のための緑化が必要であり、またそれ地震火炎時に 有効に機能するものでなくてはならない。

しかし、防火を考慮した都市緑化推進のための具体的な基淮や目 標は現在のところほとんど見られない。そこで本研究では評価にあ たり、広域擗難場所を有効面積およびリモートセンシングによる土 地被覆構成から類型化することによって相対評価する。そして各類 型の特性をふまえて、緑の防火性を活用した緑化手法を提案寸る。

土地被覆による類型化は、夏季・冬季の土地被覆分類結果をもと に作成した土地被覆分布データから、それぞれの避保場所に相当寸 る部分を抽出したものを用いる。加えて、避蜼場所周縁部の土地被 覆デー夕も抽出した。なお、避蜼場所周縁部とは、避難場所の境界 線の内側 1 ピクセルの領域とした。

避難場所周縁部の土地被覆デ一夕は、避難場所内部の有効面積確 保の観点から、各避勒場所について防火性の最む高、常緑広葉樹の 割恰を集計し、各類型ごとにそのヒストグラムを作成した。

\section{4-2 広域避䧼晅所における緑の評価}

\section{4-2-1 有效面積・土地被覆構成による庆域避蜼場所の類型化}

広域辟難場所に求められるのは周囲の市街地大火から安全な有 効面積の確保と避難十画人口一人あたりの有效面積の確保である。 そこで各避難場所の特性を、避斯証画人口一人あたり有効面積と広

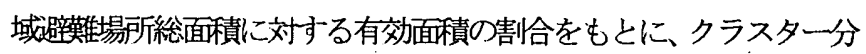

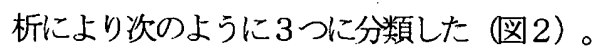

すなわち、一人あたり有効面積が極めて小さい（I 類型）、一 人あたり有効面積が小さく有効面積の割合が大きい（I類型）、一 人あたり)有効面積が大きく有効面積の割合が大きい（纤類型）、の 3類型とした。

土地被覆構成による類型化は、緑の構成の特性を把握寸るため に、各避難場所内の常緑広葉樹・落葉広葉樹・金葉樹・常緑草・夏 
緑性の草・その他の6 項目の割合をもとにクラスター分析を行い、 4 類型に分けた。図3に避傼場所の土地被覆構成による各類型の分 布を示す。

そして緑の構成の特性の各類型の特徽については、類型ごとに 土地被覆構成の平均を求めたところ、常緑広葉樹が多、(A類型)、 落葉広葉樹・針葉臌が多い(B類型)、草地が多い(C類型)、植 生が少ない(D類型)と特徵づけられた。

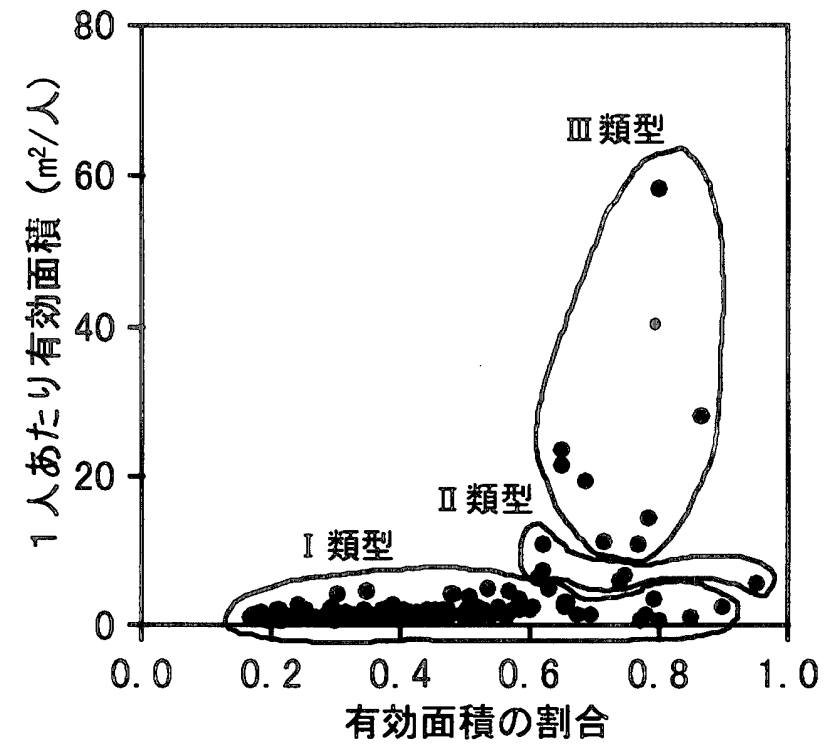

図2 有効面積による類型の分布

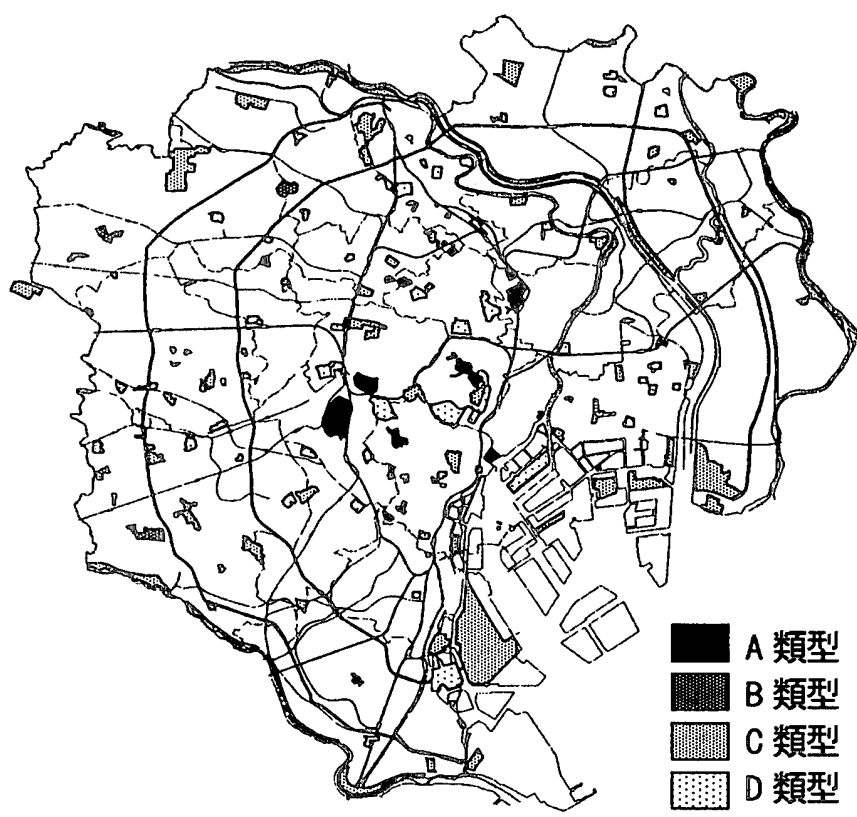

図 3 土地被覆構成による類型の分布

\section{4-2-2 緑の防火性からみ大評価と対策}

表5は、避難場所の類型別に評価と対策を示したものである。A 類型は、比較的周縁部の常緑広葉樹の割恰が多く、周縁部の防火性 も高いといえる。その一方でD類型は、周縁部の常緑広葉樹の割合 が低く、周縁部における防火対策を検討主る必要がある。

また特に対策が必要なのは、C類型における河川俌などの草の多 、避難場所で、冬季に枯れ草への引火の危険性があり、周縁部に常 緑広葉樹林を配置するなどの対策が必要である。
また、全般的に多くの避難場所においては、防火性を考慮した緑 化手法の検討が必要であるといえる。

5. おわりに

\section{5-1 結論}

本研究では、地球観測衛星によるリモートセンシングを用い 東京都区部の避蜼場所の緑について、緑の防火性を考慮した調查手 法としてリモートセンシングの応用可能性を検討した結果、以下の ような成果を得た。

1) 緑の中て防火効果の大きい常緑広葉樹の分布を把握するために、 夏季・冬季のマルチテンポラルデータを解析し、避蜼場所におけ る植生分布を把握した。

2）1ににおる夏季・冬季のデータの土地被覆分頑結果について、分 類精度は $80 \%$ 程度であった。

3）1）2）をふまえ、東京都区部の避難場所について、防火性の観点か らその緑を評価する手法を提案し、さらにこれにより避難場所 におうける緑の防火性を考慮した緑化手法を提案した。

避鞋場所の整備にあたっては、面積の確保のみならず、樹木の 防火性を活用した緑化謤画が必要である。そこでは避難場所の特性 把握するための事前評価か㴗求され、広域性・均質性・周期性に優 れる地球観泪衛星のリモートセンシングは、その基䃈調査に有効で あるといえる。

\section{5-2 今後の課題}

今回は地球観則衛星デー夕による解析調查を行ったが、今後行政 データとして実用化するためには、航空機 MSS 等の高分解能でータ と Landsat データとを用い、画素の大きさの相違に伴う土地被覆の 同定に関する比較検吋が必要である。

また、都市緑化推倠に関しては、量に重点を置いた緑化のほか飞、 防火性等の緑の質を考慮した緑化推進のための基淮づくりが求め られ、そのための計測手法の開発やデー夕の蓄積が必要である。

\section{謝辞}

本研究を進めるにあたり、市川健君（日本工営、当時早稲田大学 大学院生)の協力を受けました。ここに謝意を表します。

\section{本研究人関する既発表論文}

1) 鍵屋造司：リモートセンシングを用いた広域避難場所における 緑の評価，第 20 回 (平成 8 年度春季) 日本リモートセンシング 学会学術講演会論文集，pp. 9-12，1996.5

2）市川徤・鍵屋浩司・尾島俊雄 : リモートセンシングを用いた広 域避難場所における緑の評価，(その1) マルチテンポラルデー 夕の解析・(その 2) 緑の分布による広域避難場所の評価とその 対策, 1996 年度日本建築学会大会学術講演梗概集 (近畿), pp. 517-520, 1996.9

注記

本研究て使用した Landsat デー夕は、宇宙開発事業団より提供を 受けたものである。

「衛星デ一夕所有 : 米国政府」

「衛星デー夕提供 : EOSAT/宇宙開発事鄴団」 
表 5 広域避難場所の緑の評価および対策

\begin{tabular}{|c|c|c|c|c|c|}
\hline \multirow{2}{*}{\multicolumn{2}{|c|}{ 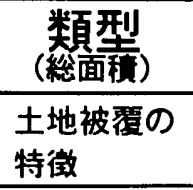 }} & $\begin{array}{l}\text { A類型 } \\
\text { (509ha) }\end{array}$ & $\begin{array}{l}\text { B類型 } \\
\text { (214ha) }\end{array}$ & C頪型 & $\begin{array}{l}\text { D頪型 } \\
\text { (1598ha) }\end{array}$ \\
\hline & & 常緑広茶樹が多い & 落葉澍・針葉樹が多い & 草地が多い & 植生が少ない \\
\hline \multicolumn{2}{|c|}{$\begin{array}{l}\text { 土地被覆の } \\
\text { 代表的構成 }\end{array}$} & (明治神宮・代々木公園一带) & (砧公園・大藏弾動公園一带) & (江戸川南部一带) & (R日田端・尾久操車場) \\
\hline \multirow{3}{*}{$\begin{array}{l}\text { 避 } \\
\text { 難 } \\
\text { 場 } \\
\text { 所 } \\
\text { 名 }\end{array}$} & I 類型 & $\begin{array}{l}\text { 明治神宮·代々木公園一帯 } \\
\text { 新宿御苑 他14策所 } \\
\end{array}$ & $\begin{array}{l}\text { 谷中基地 } \\
\text { 清澄庭園 他 } 4 \text { 箇所 }\end{array}$ & $\begin{array}{l}\text { 光か兵団地・光が兵公葍一带 } \\
\text { 皇居前広場・日比谷公團 } \\
\text { 他63筒所 }\end{array}$ & 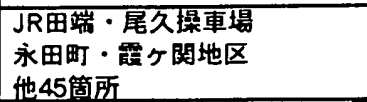 \\
\hline & I類型 & & 砧公園・大荗運動公園一帯 & $\begin{array}{l}\text { 多摩川河川敷・六郎撟一帯 } \\
\text { 東京国祭空港 他 } 3 \text { 箇所 }\end{array}$ & \\
\hline & III類型 & & & $\begin{array}{l}\text { 江戸川南部一帯 } \\
\text { 大井埠頭一带 他 } 5 \text { 箇所 }\end{array}$ & 晴海地区 \\
\hline \multicolumn{2}{|c|}{$\begin{array}{l}\text { 周緑部の } \\
\text { 常緑広葉樹 } \\
\text { の割合 }\end{array}$} & 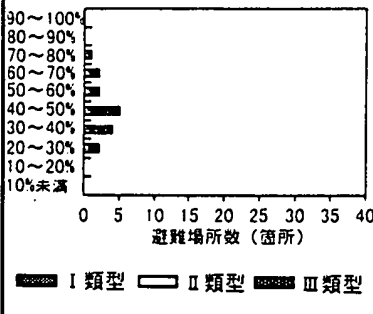 & 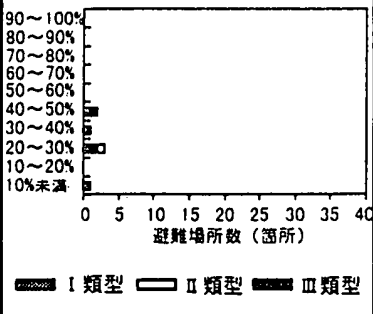 & 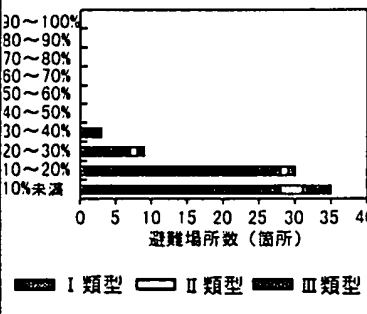 & 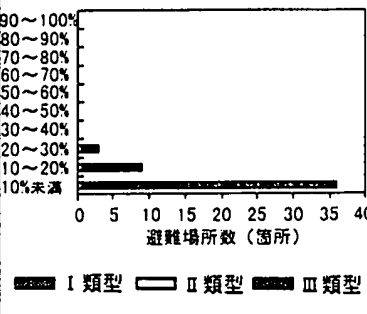 \\
\hline \multirow{3}{*}{ 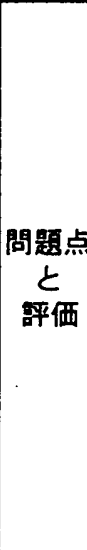 } & I 類型 & $\begin{array}{l}\text { 内部・周緑部ともに常緑 } \\
\text { 広葉澍が多く、防火性に } \\
\text { 镸れる }\end{array}$ & $\begin{array}{l}\text { 周緑部の防火性は比較的 } \\
\text { 期待できるが、枯れ木 } \\
\text { 枯草への引火の可能性が } \\
\text { ある }\end{array}$ & $\begin{array}{l}\text { 周緑部の緑の防火性が低 } \\
\text { く、さらに枯草への引火 } \\
\text { の可能性がある }\end{array}$ & $\begin{array}{l}\text { 緑の防火性は期待できず } \\
\text { また } 1 \text { 人当たりの有効面 } \\
\text { 樌も小さい }\end{array}$ \\
\hline & II 類型 & & $\begin{array}{l}\text { 有効面箖の割合及び周緑 } \\
\text { 部の緑の防火性が比较的 } \\
\text { 大きいが、枯れ木・枯草 } \\
\text { への引火の可能性がある }\end{array}$ & $\begin{array}{l}\text { 周緑部の緑の防火性が低 } \\
\text { く、さらに枯草への引火 } \\
\text { の可能性がある }\end{array}$ & \\
\hline & IIII類型 & & & $\begin{array}{l}\text { 有効面皘の割合が大きく } \\
1 \text { 人当たりの有効面樌も } \\
\text { 大きいか、、冬季に枯草へ } \\
\text { の引火の可能性がある }\end{array}$ & $\begin{array}{l}\text { 植生は少ないか：有効面 } \\
\text { 積の割合および } 1 \text { 人当た } \\
\text { りの有効面樌が大きい }\end{array}$ \\
\hline \multirow{3}{*}{ 対策 } & I 類型 & ・現状を維持する & $\begin{array}{l}\text { ・周緑部に常緑広葉澍の } \\
\text { 樹林帯を整備する } \\
\text { ・落莱等の処理を行う } \\
\text { ・撒水設備を設ける }\end{array}$ & $\begin{array}{l}\text { ・周緑部に常緑広萧樹林の } \\
\text { 榯林带を重点的に整備す } \\
\text { る }\end{array}$ & $\begin{array}{l}\text { ・周緑部に常緑広莱樹の } \\
\text { 澍林帯を整備する } \\
\text { ・周囲の建造物を耐火造 } \\
\text { にする }\end{array}$ \\
\hline & III 類型 & & • 落葉等の処理を行う & $\begin{array}{l}\text { ・周緑部に常緑広葉樹林の } \\
\text { 榯林帯を整備する }\end{array}$ & \\
\hline & III 類型 & & & $\begin{array}{l}\text { ・周緑部に常緑広葉樹林の } \\
\text { 樹林带を整備する }\end{array}$ & ・現状を維持する \\
\hline
\end{tabular}


注）庆域辟保住昜所の有効面䅡算定の概要 ${ }^{211}$

(1)広域壀住場所候補地の選定

短刀 $300 \mathrm{~m}$ 以上で、影地面䅡 $10 \mathrm{ha}$ 以上の空地（さら地・緑地带・耐火建築群・ 木造建策物があっても建蔽率 $2 \%$ 以下等)。

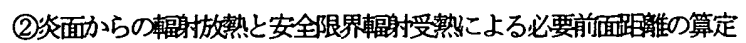

·安全限界輻射受等 : $2050 \mathrm{kcal} / \mathrm{m}^{\mathrm{m} h}$ (人間に対して)

. 炎面の諸仮定数值 : 緟面温度 $850^{\circ} \mathrm{C}$ 、輝面率 0.5 として輻射放熱 $39,350 \mathrm{kcal} / \mathrm{m}^{\mathrm{h}} \mathrm{h}$

- 角関係 形態衫数) は $\phi=2,050 / 39,350=0.0521$

炎の形と大きさを下図のようにモデル (斜6面体) 化し、上記の設定值より許 容角関倸以下になる距離N（必要前面距離）を算定寸る。

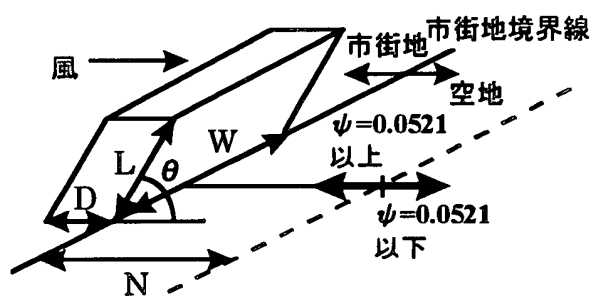

$\theta=$ 资の風下こおける傾き角 $\tan \theta=4 \mathrm{D} \cdot \mathrm{m} \cdot \mathrm{n} / \mathrm{v}^{2}$

$\mathrm{L}=$ 资の長さ $(\mathrm{m}) \quad \mathrm{W}=$ 市街地正面幅 (火多幅) $\mathrm{D}=$ 火災奥行 $(\mathrm{m}): \mathrm{D}=\mathrm{V} \cdot \mathrm{t}$ $\mathrm{m}=$ 平均建敬率 $\mathrm{n}=$ 延娔速度比 $\mathrm{v}=$ 風速 $(\mathrm{m} / \mathrm{s}) \mathrm{V}=$ 火災の延妩速度 $(\mathrm{m} / \mathrm{h})$ $t=1$ 唓が着火してから燃え落ちまでの时間 (h)

また、必要前面距離を算定する条件として、次の効果を見迅場合がある。 1.市街地境界にある耐火建物の効果

2.奥行きの肼、市街地の効果

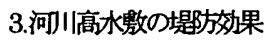

4.崖の高低差による効果

5.樹木の有無こよる効果

(3)有效面稘の算定

広城辟蜼場所の周囲の市街地境界線から必要前面跑離をとった領域の面䅐が 安全面梲で、これをもとに下式によって有效面積を算定する。

$B=\left\{A_{1}+\left(A-A_{1}\right) \alpha\right\} \quad B$

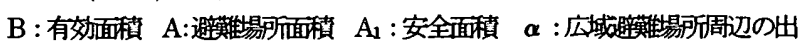

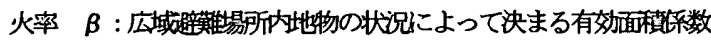

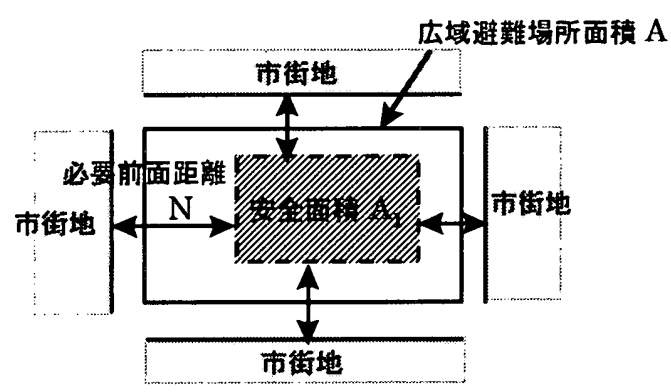

\section{参考文献}

1) 田中八百八 : 大正の大地震及び大火と帝都の樹園, 山林争報（臨時增 FD), ppl-29, 1923

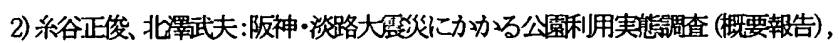
公園緑地 Vol. 55, No. 6, 1995

3）阪神大招災調查特别委員会 : 公園緑地などに関寸る阪神大霞災緊急調查報告

㶳, 日本造園学会, 1995. 6

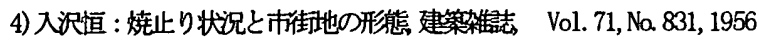

5)岩河信文 : 橔木の被害の概況 酒田市大火調查速報, 1976

6) 東京都絰務局 : 第5 次東京都震災予防計画 東京都情報連絡室, 1995, pp. 121122

7)東京都防災会議：東京都地域防災計画 霞災編（平成 4 年修 正), 1993, pp663-676
8) 尾島俊雄 : 環境場㔀定のSpace Modular Coordination Chart, (その1) 時空間 分割情、日本建築学会論文報告集 No. 319,pp. 84-89, 1982.9；（その2）実用 化への考察，日本建学学会論文報告集 No. 320, pp. 108-111, 1982.10

9)依田浩敏・尾島俊雄: 広域災害に扔けるリモートセンシング利用に闦する研究 一東京都区部の広域避難場所の検討-, 日本建築学会計面系論文報告 集 No. 411, pp. 1-8, 1990.5

10)井上桂・中元六雄: 檄葉の燃焼 日本林学会誌 33(3) (4), 1951

11) 中村貞一：做林の防火力の研究 (第 1 報) 緑地用樹木の葉の含水释之脱水時 間についての比較実験, 造園脎倍誌 Vol. 12, №. 1, 1948.11

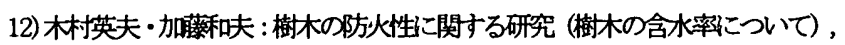
造園犰拮志 Vol. 11, №. 1, 1948, 3

13)岩河信文 : 樹木の防火力と防火対策への適用，建䓩研究報告 105,1984

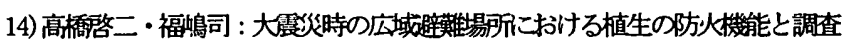
方法について,森林立地 Vol. 131, No. 2, 1980

15)福鴄司・門屋健 : 楜木の構成之配置力らみ大者阨公園の防火機能に閉寸る研 究 森林立地 Vol. 131, No. 2, 1990

16) 新田伸三 : 澴境緑地口植栽の理侖と技術, 鹿島出版会 pp. 132-136, 1975

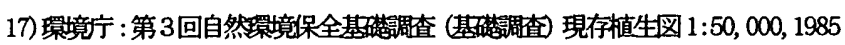
18) 東京都瑮境保全局自然呆護部 : 東京都見存植生図 1:25, 000, 1987

19)財団法人野外自然尃物館後援会 : 自然教育園現存植生図 1:1000, 1967

20) 高木幹雄・下田陽入 : 画像解析ハントブック, 東京大学恃版会, 1992, pp.684685

21）日本火災学会 : 新版 建案新火教材, 日本火災学会, 1980, pp. 150-151

（1997年 1 月 10 日原稿受理，1997年 4 月 4 日探用決定） 